\title{
Temperature reduction in internal soft tissues in relation to rectal temperature in dogs in the early post-mortem period
}

\author{
Piotr Listos $^{1 *}$, Magdalena Gryzińska², Justyna Batkowska ${ }^{2}$, \\ and Malgorzata Dylewska ${ }^{2}$ \\ ${ }^{I}$ Department of Pathological Anatomy, Faculty of Veterinary Medicine, University of Life Sciences in Lublin, \\ Lublin, Poland \\ ${ }^{2}$ Department of Biological Basis of Animal Production, Faculty of Biology, Animal Sciences and Bioeconomy, \\ University of Life Sciences in Lublin, Lublin, Poland
}

LISTOS, P., M. GRYZIŃSKA, J. BATKOWSKA, M. DYLEWSKA: Temperature reduction in internal soft tissues in relation to rectal temperature in dogs in the early post-mortem period. Vet. arhiv 88, 225-234, 2018.

\section{ABSTRACT}

Until recently the rectum was the main site of temperature measurement in a carcass, due to its wellknown heat loss mechanism. For more precise determination of time of death, researchers have begun to look for additional sites for temperature reading, such as the brain or soft tissues. Hence the main objective of the study was to compare the temperature reduction in the soft tissues of internal organs with the decrease in rectal temperature in a dog carcass. As most literature data pertain to humans, whereas in animals such measurements are performed sporadically, we aimed to investigate the potential use of post-mortem measurement of the heart, lung and liver temperature in a dog in order to establish the time of its death. The material for the study consisted of $20 \mathrm{dog}$ carcasses divided into two weight groups (small - up to $15 \mathrm{~kg}$ and large - over $15 \mathrm{~kg}$ ). The difference in temperature reduction between the small and large dogs was statistically significant, while the type of organ was not found to affect the rate of the decline in temperature.

Key words: veterinary forensics; time of death; post-mortem temperature; heart; lung; liver

\section{Introduction}

The phenomenon of death is an important subject of research in medical and forensic science. Establishing the time of death, in both humans and animals, is crucial both for science and for the work of the judicial bodies (PIÓRKOWSKI et al., 2010; SZCZEPANIAK et al., 2012). Determination of the exact time of death is a complex

\footnotetext{
${ }^{*}$ Corresponding author:

Piotr Listos, PhD, Assistant Professor, University of Life Sciences in Lublin, Faculty of Veterinary Medicine, Department of Pathological Anatomy, Gleboka 30, 20-612 Lublin, Poland, Phone: +48 81445 6161; E-mail: piotr.listos@up.lublin.pl
} 


\section{P. Listos et al.: Temperature reduction in dogs in the early post-mortem period}

process which must take into account numerous environmental, physical and biochemical factors affecting the changes taking place in the body immediately after death. Accurate determination of the post-mortem interval in an animal is a key piece of information when a crime has been committed, placing it within a specific time range, so that the judicial bodies can more easily identify the perpetrator. This is the task of the expert veterinarian or coroner examining the body (ERLANDSSON and MUNRO, 2007; LISTOS et al. $2015,2016 \mathrm{c})$. There are several methods, of varying accuracy, for determining time of death, such as evaluation of post-mortem changes (both early and late) or measurement of rectal temperature. Alternative methods are continually being sought in order to specify the time of death as precisely as possible. Increasingly accurate measuring devices are accelerating efforts to establish the truth. Recently reported cases in which the victims have included animals necessitate estimation of the time of their death (NOZDRYNPLOTNICKI et al., 2005; MUNRO and MUNRO, 2008; BANKA et al., 2010).

Routine methods used in medicine and veterinary forensics to determine the time and cause of death include examination of post-mortem changes, such as paleness (pallor mortis), cooling of the body (algor mortis), stiffness (rigor mortis), and lividity (livores mortis) (MARCINKOWSKI, 1975; RASZEJA, 2005). One of the earliest methods used to determine time of death was measurement of rectal temperature. This method is simple, but subject to substantial error, which may be the result of individual characteristics, diurnal fluctuations in temperature, ambient conditions, or differences in the depth at which the temperature is taken (ŚLIWKA and MIŚCICKA-ŚLIWKA, 1985). There are few literature data on post-mortem temperature in the internal soft tissues of animals. Methods for determining time of death on the basis of body temperature date back to the mid- $19^{\text {th }}$ century, but the most significant research development took place in the $20^{\text {th }}$ century, when a nomogram for reading off the time of death was developed (HENSSGE, 1988; HENSSGE and MADEA, 2004). Studies based on temperature, not only in the rectum, but also in the brain, liver, and vitreous humour of the eye (ŚLIWKA and MŚCICKA-SLIWKA 1984; LISTOS et al., 2016a), have contributed to the creation of computer software accelerating and facilitating computation of time of death in humans (HADLEY et al., 1999; BURGER et al., 2013). Ideally a nomogram would be developed for reading the post-mortem interval for dogs, cats or livestock animals, i.e. animals which most often accompany human beings.

In seeking a new, alternative method for establishing the post-mortem interval in dogs shortly after their death, we chose to direct our study towards determination of the temperature reduction in the soft tissues of internal organs. The aim of the study was to test the suitability of the heart, lung and liver of dogs as sites for temperature measurement to establish time of death. 
P. Listos et al.: Temperature reduction in dogs in the early post-mortem period

\section{Material and methods}

Animals. The study was conducted on 20 carcasses of dogs that died at the age of 7 to 16 years. The dogs weighed from 4.5 to $48 \mathrm{~kg}$. The animals were divided into two weight groups. The first group, with 11 individuals, consisted of small dogs (up to 15 $\mathrm{kg}$ ), and the second, with 9 individuals, comprised large dogs (over $15 \mathrm{~kg}$ ). The animals were euthanized due to advanced age-related health problems or generalized cancer. Only cases in which the time of death could be precisely and unquestionably determined on the basis of medical history were included in the study. All the animals used in the study had intact skin and were covered with a short coat of hair.

Study procedures. The carcasses were stored in a room in which the temperature, humidity and air flow were continuously measured. The results were recorded every 10 min using an anemometer (Airflow TA-440A). The physical parameters of the air, which were constant over the entire study period, were as follows: temperature $18{ }^{\circ} \mathrm{C}$, relative humidity $65 \%$ and mean air flow $0.1 \mathrm{~m} / \mathrm{s}$. These external physical factors did not affect the results of the study. The rectal, heart, lung and liver temperature were measured every half hour for 12 hours from the time of death. A temperature probe was inserted into the rectum to a depth of $40 \mathrm{~mm}$. In the case of the other organs, a probe was inserted under ultrasound guidance. No necropsy was performed on the carcasses. The first measurement of internal temperature was taken when the animal was euthanized. Temperature was measured with a TERMIO-25P electronic thermometer, accurate to $\pm 0.01{ }^{\circ} \mathrm{C}$ in conjunction with a $4 \mathrm{~mm}$ x $120 \mathrm{~mm}$ ST-02 temperature probe (Termoprodukt, Poland).

Statistical analyses. Statistical analysis of the data was performed using the SPSS 20.0PL statistics package (IBM, 2011). Normality of the distribution was tested by the Shapiro-Wilk test. An attempt was made to analyse the data by multivariate analysis of variance with interaction, but because the interaction of the factors (body weight and age of the animal, initial body temperature) was not significant, we focused exclusively on the means for the main factors. Significance of differences was verified by Student's t-test (2 groups) and one-way analysis of variance ( 3 and more groups). The relationships between characteristics were also assessed by determining parametric correlations. In addition, in cases where Pearson's coefficients were significant, linear regression coefficients were calculated and regression lines were plotted.

\section{Results}

The mean weight of the small dogs was $8.88 \mathrm{~kg}$, while that of the large dogs was $35.53 \mathrm{~kg}$. At the time of euthanasia, the mean temperature in the organs was $38.65^{\circ} \mathrm{C}$ in the small dogs and $38.30^{\circ} \mathrm{C}$ in the large dogs. Analysis of the results obtained for mean temperatures measured in the rectum and internal soft tissues at different time intervals after the dogs were euthanized indicates a gradual decline in temperature over time 


\section{P. Listos et al.: Temperature reduction in dogs in the early post-mortem period}

(Fig. 1). In the first group (small dogs) the mean temperature in all the organs studied decreased faster than in the organs of the large dogs. On the basis of statistical analysis, no significant differences were found between the internal organs depending on the body weight of the dogs, only a general difference between the groups of dogs (regardless of the internal organ) when the difference in the mean temperature reduction was significant $\left(\mathrm{p} \leq 0.05\right.$ ), amounting to 15.27 and $13.85{ }^{\circ} \mathrm{C}$, respectively in the groups of smaller and larger animals.

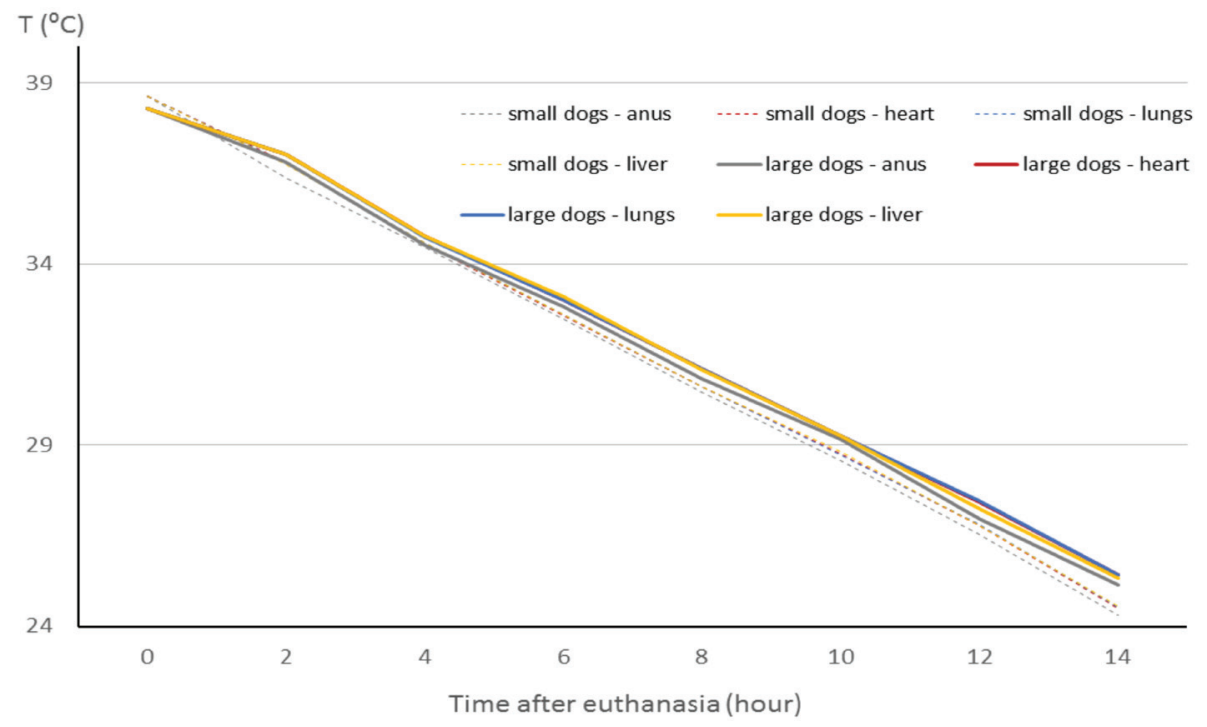

Fig. 1. Mean rectal, heart, lung and liver temperatures in the groups of small and large dogs

A comparative analysis was conducted between the mean differences in the rectal, heart, lung and liver temperatures in the groups of small and large dogs between the $1^{\text {st }}$ and $15^{\text {th }}$ hour after euthanasia, at two-hour intervals (Fig. 2). A greater temperature amplitude was noted in the group of small dogs than in the large dogs, except for at the $5^{\text {th }}$ and $11^{\text {th }}$ hour after death. The greatest difference in temperature, about $2.9^{\circ} \mathrm{C}$, was noted for the lungs in small dogs between the $1^{\text {st }}$ and $3^{\text {rd }}$ hour post-mortem.

An analysis was also performed of the dynamics of the temperature decrease in the groups of small and large dogs for all organs combined, and the difference in temperature was compared between these groups at each time interval (Fig. 3). Analysis of differences in body temperature indicates that it was higher in the group of large dogs, except for the first measurement at the time of euthanasia (when it was higher for small dogs). After death the difference in temperature successively increased for large dogs, from $0.17{ }^{\circ} \mathrm{C}$ ( $4^{\text {th }}$ hour after death) to $0.86^{\circ} \mathrm{C}$ (14 th hour) (Fig. 3). 
P. Listos et al.: Temperature reduction in dogs in the early post-mortem period

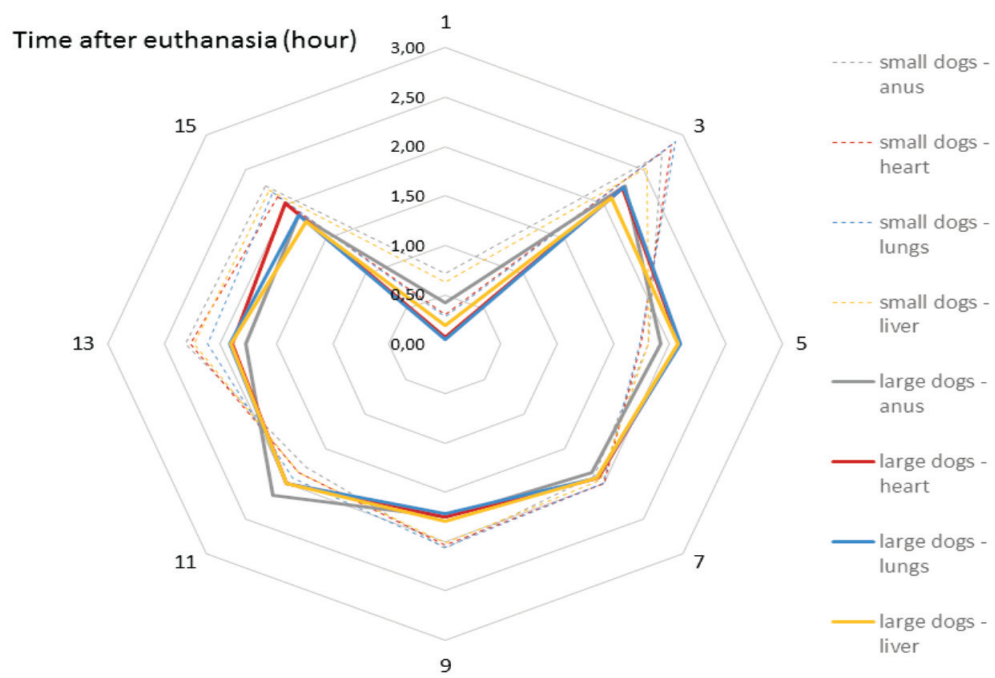

Fig. 2. Differences in rectal, heart, lung and liver temperatures in the groups of small and large dogs at 2-hour intervals

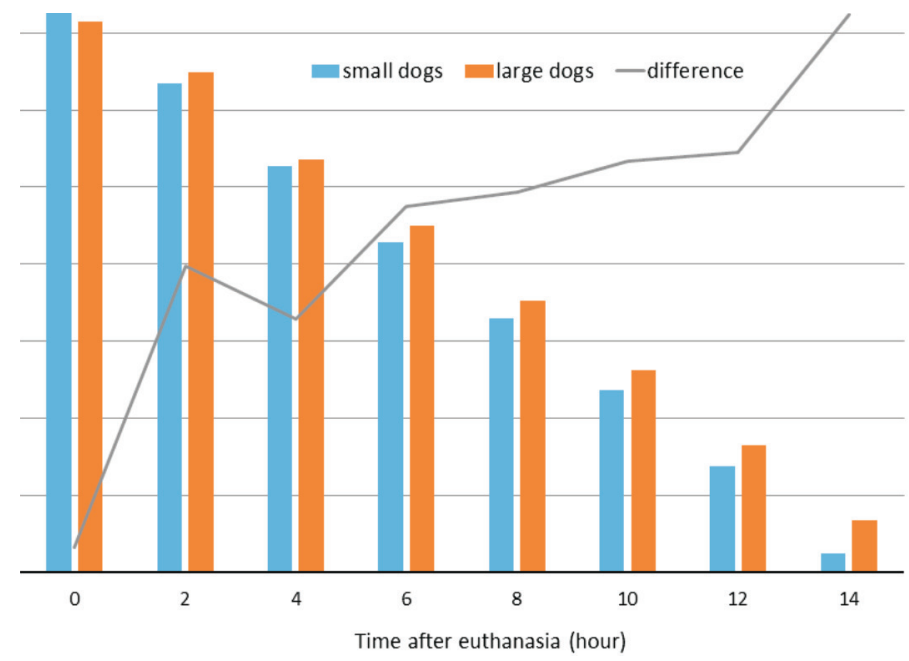

Fig. 3. Mean temperatures and differences in temperature between small and large dogs 


\section{P. Listos et al.: Temperature reduction in dogs in the early post-mortem period}

\section{Discussion}

Temperature-based methods for estimating time of death, based on analysis of the cooling of the carcass and involving temperature measurements in various parts of the body, are considered to be more accurate than methods based on evaluation of other postmortem processes taking place in the body, particularly in the initial period after death (up to about $20 \mathrm{~h}$ ) (HENSSGE and MADEA, 2004). Measurements of this type have mainly been performed in humans, and only sporadically in animals. The development of veterinary forensics has led to studies on this subject in dogs, pigs and deer (HIRAIWA et al., 1981; AL-ALOUSI et al., 2001).

The first scientific reports on the decrease in body temperature after death date back to the $19^{\text {th }}$ century, and concern humans. Methods for determining time of death are still far from perfect. It is difficult to establish the exact time of death; usually a wide time interval is given.

Studies have involved measurement of skin temperature, e.g. of the groin (SEYDELER, 1869), forehead (LYLE and CLEVELAND, 1956), and chest (WOMACK, 1887); the temperature of internal organs, such as the liver (AL-ALOUSI et al., 2001), brain, heart (ŚLIWKA and MŚCICKA-SLIWKA, 1984), trachea (NOKES et al., 1986) and muscles (LYLE and CLEVELAND, 1956); and that of natural body cavities: the rectum (HANSSGE and MADEA, 2004; LISTOS et al. 2016a,b), ear, and nose (NOKES et al., 1992). These studies have established that deep measurement points are most useful for determining the post-mortem interval. The brain in the first 6 hours after death is considered to provide the most objective temperature measurement in humans, followed by the liver, rectum, and ear canal (AL-ALOUSI et al., 2001).

In the case of dog carcasses, studies have used measurements of the liver, brain, aural and rectal temperature to determine the post-mortem interval (PROCTOR et al., 2009). Sex and hair coat density were not found to affect the rate of reduction in body temperature, while increased body weight and volume slowed it down. Similar conclusions were drawn in a study on the temperature reduction in the eyes of pigs (KALISZAN and HAUSER, 2007). We observed similar relationships for the heart, lung, liver and rectal temperature. The temperature reduction between the groups of small and large dogs was statistically significant. In contrast, body weight has been shown to have no effect on temperature reduction in the brain (SIMONSEN et al., 1977).

In our study, the type of organ was not found to affect the rate of temperature reduction. In both the small and large dogs the temperature for each time interval was similar for the heart, lung, liver and rectum, although it declined faster in the rectum. Similar findings have been reported for the liver and rectum (DE SARAM, 1957), but differences in temperature reduction have been noted between the rectum and kidney 
(LISTOS et al. 2016b) and between the rectum and orbit (LISTOS et al. 2016a), with a faster rate of decline for the rectal temperature.

According to MARCINKOWSKI (1975), rectal temperature in humans decreases $1{ }^{\circ} \mathrm{C} / \mathrm{h}$ for 6-9 hours. However, the post-mortem plateau effect should be taken into account. It lasts up to about 3 hours post-mortem and during this time the temperature reduction is very slight (KALISZAN et al., 2005; HUBIG et al., 2011; KALISZAN, 2012). In the present study the temperature reduction in the heart, lung and liver of the dogs showed no post-mortem plateau, and was slow in the initial post-mortem period. The results of the study are consistent with those obtained by KALISZAN and HAUSER (2007), who also did not observe a post-mortem plateau for the eyes or orbital soft tissues of pigs.

The error in estimating the post-mortem interval on the basis of measurements of heart, lung and liver temperature is comparable, and enables more accurate estimation of time of death for at least $10 \mathrm{~h}$ post-mortem than in the case of temperature (BACCINO et al., 1996; KALISZAN et al., 2005).

Modelling of the dynamics of the temperature reduction in dog carcasses at an ambient temperature of $18{ }^{\circ} \mathrm{C}$ to some extent limits its potential for universal application in forensic practice. Diagrams must be established for other ambient conditions. Nevertheless, it seems that comprehensive evaluation of the phenomenon of body cooling, accompanied by gradation of the suitability of different measurement points for determining the postmortem interval, will provide coroners with a more critical approach to the problem of establishing time of death by measuring the temperature of internal organs (LISTOS et al., 2016a).

\section{Conclusions}

By taking into account information on temperature reduction in various parts of the body for different animals, we are raising the quality of research in veterinary forensic medicine to a new level. Determining the temperature reduction in the soft tissues of internal organs, relative to the decline in rectal temperature, enables precise specification of the time of the animal's death. The results of the study indicate that determination of temperatures in the internal soft tissues and rectum in the initial period of death is justified and repeatable. Measurements of the temperature of internal tissues should take body weight into account, because it proved to be a statistically significant factor.

\section{Acknowledgements}

We thank Ms. Sara Wild for translating this manuscript. 


\section{P. Listos et al.: Temperature reduction in dogs in the early post-mortem period}

\section{References}

AL-ALOUSI, L. M., R. A. ANDERSON, D. M. WORSTER, D. V. LAND (2001): Multipleprobe thermography for estimating the postmortem interval: I. Continuous monitoring and data analysis of brain, liver, rectal and environmental temperatures in 117 forensic cases. J. Forensic Sci. 46, 317-322.

BACCINO, E., L. DE SAINT MARTIN, Y. SCHULIER, P. GUILLOTEAU, M. LE RHUN, J. F. MORIN, D. LEGLISE, J. AMICE (1996): Outer ear temperature and the time of death. Forensic Sci. Int. 83, 133-146.

BAŃKA, K., G. BUSZEWICZ, P. LISTOS, R. MĄDRO (2010): Usefulness of GC-MS method for the determination of DDT, DMDT, and $\gamma-\mathrm{HCH}$ in bees (bodies) for legal purposes. Bull. Vet. Inst. Pulawy 54, 655-659.

BURGER, E., J. DEMPERS, S. STEINER, R. SHEPHERD (2013): Henssge nomogram typesetting error, Forensic Sci. Med. Path. 9, 615-617.

DE SARAM, G. S. W. (1957): Estimation of the time of death by medical criteria. J. Forensic Med. 4, 47-57.

ERLANDSSON, M., R. MUNRO (2007): Estimation of the post - mortem interval in beagle dogs. Sci. Justice 47, 150-154.

HADLEY, B. M., L. W. ROBBINS, D. A. BEFFA (1999): Estimating time of death of deer in Missouri: a comparison of three indicators. J. Forensic Sci. 44, 1124-1130.

HENSSGE, C. (1988): Death time estimation in case work. I. The Rectal temperature time of death nomogram, Forensic Sci. Int. 38, 125-133.

HENSSGE, C., B. MADEA (2004): Estimation of the time Since Heath in the early post-mortem period. Forensic Sci. Int. 144, 123-133.

HIRAIW, A K., T. KUDO, F. KURODA, Y. OHNO, I. M. SEBETAN, S. OSHIDA (1981): Estimation of post-mortem interval from rectal temperature by use of computer: relationship between the rectal and skin cooling curves. Med. Sci. Law. 1, 4-9.

HUBIG, M., H. MUGGENTHALER, G. MALL (2011): Influence of measurement errors on temperature-based death time determination, Int. J. Legal Med. 125, 503-517.

KALISZAN, M. (2012): First practical applications of eye temperature measurements for estimation of the time of death in casework. Report of three cases, Forensic Sci. Int. 219, 13-15.

KALISZAN, M., R. HAUSER (2007): Estimation of the time of death based on the measurements of the eye temperature in comparison with other body sites. Arch. Med. Sąd. 57, 399-405.

KALISZAN, M., R. HAUSER, R. KALISZAN, P. WICZLING, J. BUCZYŃSKI, M. PENKOWSKI (2005): Verification of the exponential model of body temperature decrease after death in pigs. Exp. Physiol. 90, 727-738.

LISTOS, P., M. GRYZINSKA, J. BATKOWSKA (2016a): Postmortem decrease in temperature in the orbit of dogs for use in determining time of death. Slov. Vet. Res. 53, 85-90.

LISTOS, P., M. GRYZINSKA, J. PIORKOWSKI, G. TERESINSKI, G. BUSZEWICZ, W. CHAGOWSKI, Z. NOZDRYN-PLOTNICKI, W. LOPUSZYNSKI (2016b): Post-mortem 


\section{P. Listos et al.: Temperature reduction in dogs in the early post-mortem period}

estimation of time of death of dogs based on measurements of kidney temperature in comparison with rectal temperature. Acta Vet. Belgrade 66, 78-88.

LISTOS, P., M. GRYZINSKA, M. KOWALCZYK (2015): Analysis of cases of forensic veterinary opinions produced in a research and teaching unit. J. Forensic Leg. Med. 36, 84-89.

LISTOS, P., P. KOMSTA, W. LOPUSZYNSKI, M. GRYZINSKA, G. TERESINSKI, W. CHAGOWSKI, W. BUSZEWICZ, M. DYLEWSKA (2016c): Radiological and forensic veterinary analysis of gunshot cases. Med. Weter. 72, 616-619.

LYLE, P. H., F. P. CLEVELAND (1956): Determination of the time of death by body heat loss. J. Forensic Sci. 1, 11-23.

MARCINKOWSKI, T. (1975): Forensic Medicine for Lawyers. Wydawnictwo Prawnicze, Warsaw, pp. 148-161, 313-314 (in Polish).

MUNRO, R., H. MUNRO (2008): Animal Abuse and Unlawful Killing. Saunders Elsevier, Edinburgh and London p. 92.

NOKES, L. D. M., B. HICKS, B. KNIGHT (1986): The use of trachea temperature as means of determining the post-mortem period. Med. Sci. Law 26, 199-202.

NOKES, L. D. M., T. FLINT, S. JAAFAR, B. H. KNIGHT (1992): The use of either the nose or outer ear as a means of determining the postmortem period of a human corpse. Forensic Sci. Int. 54, 153-158.

NOZDRYN-PŁOTNICKI, Z., P. LISTOS, W. ŁOPUSZYŃSKI, P. DĘBIAK (2005): Section investigation of animals wounded from fire arms: some remarks. Med. Weter. 61, 887-889.

PIÓRKOWSKI， J., Z. NOZDRYN-PŁOTNICKI， P. LISTOS (2010): Evaluation of pathomorphological splenic lesions in dogs from the Lublin region in 2005-2008. Bull. Vet. Inst. Pulawy. 54, 243-246.

PROCTOR, K. W., W. J. KELCH, J. C. Jr. NEW (2009): Estimating the time of death in domestic canines. J. Forensic Sci. 54, 1433-1437.

RASZEJA, S. (2005): Some remarks on thanatology - classical branch of forensic medicine. Ann. Acad. Med. Gedan. 35,165-172.

SEYDELER, R. (1869): Nekrothermometrie. Vierteljahrschrift für die Praktische Heilkunde. 26, 137-148.

SIMONSEN, J., J. VOIGT, N. JEPPESEN (1977): Determination of the time of death by continuous postmortem temperature measurements. Med. Sci. Law 17, 112-122.

ŚLIWKA, K., D. MIŚCICKA-ŚLIWKA (1984): The examinations on body cooling with regard to estimating the time of death. I. Post-mortem temperature droap in brain. Arch. Med. Sąd. i Krym. 34, 223-232.

ŚLIWKA, K., D. MIŚCICKA-ŚLIWKA (1985): The examinations on body cooling with regard to the estimation of the time of death. II. Post-mortem temperature drop in rectum. Arch. Med. Sąd. i Krym. 35, 1-6. 
P. Listos et al.: Temperature reduction in dogs in the early post-mortem period

SZCZEPANIAK, K., P. LISTOS, W. ŁOPUSZYŃSKI, T. SKRZYPEK, W. KAZIMIERCZAK (2012): Granulomatous peritonitis in a European brown bear caused by Baylisascaris transfuga. J. Wildl. Dis. 48, 517-519.

WOMACK, F. (1887): The rate of cooling of the body after death. St. Bart's Hosp. Rep. 23, 193-200.

Received: 18 November 2016

Accepted: 10 May 2017

\section{LISTOS, P., M. GRYZIŃSKA, J. BATKOWSKA, M. DYLEWSKA: Sniženje temperature u unutarnjim mekim tkivima u odnosu na rektalnu temperaturu u pasa u ranom postmortalnom razdoblju. Vet. arhiv 88, 225-234, 2018.}

\section{SAŽETAK}

Sve donedavno rektum je bio glavno mjesto za mjerenje temperature u lešini zbog dobro poznatog mehanizma gubitka topline. Radi što točnijeg utvrđivanja trenutka smrti znanstvenici su počeli tražiti dodatna mjesta za mjerenje temperature, kao što je mozak ili meka tkiva. Stoga je glavni cilj ovoga istraživanja bio usporediti vrijeme sniženja temperature u mekim tkivima unutarnjih organa s vremenom sniženja rektalne temperature u lešinama pasa. S obzirom na to da se većina literaturnih podataka odnosi na čovjeka, dok se u životinja ta mjerenja provode sporadično, cilj je ovoga rada bio istražiti mogućnost postmortalnog mjerenja temperature srca, pluća i jetre u pasa, kako bi se ustanovilo vrijeme njihova uginuća. Mjerenja su provedena na 20 lešina pasa podijeljenih u dvije skupine prema tjelesnoj masi (do $15 \mathrm{~kg}$ i više od $15 \mathrm{~kg}$ ). Razlika u vremenu sniženja temperature između dviju skupina bila je značajna, dok razlika u stupnju sniženja temperature pojedinih organa nije ustanovljena.

Ključne riječi: veterinarska forenzika; vrijeme uginuća; postmortalna temperatura; srce; pluća; jetra 